Review

\title{
Assessing Time of Eating in Commensality Research
}

\author{
Henrik Scander 1,*(D), Maria Lennernäs Wiklund ${ }^{2}$ and Agneta Yngve ${ }^{3,4}$ (D) \\ 1 School of Hospitality, Culinary Arts and Meal Science, Örebro University, 71202 Grythyttan, Sweden \\ 2 Department of Occupational and Public Health Sciences, Gävle University, 80176 Gävle, Sweden; \\ maria.lennernas@hig.se \\ 3 School of Health Sciences, Örebro University, 70281 Örebro, Sweden; agneta.yngve@oru.se \\ 4 Department of Nutrition, Dietetics and Food Studies, Uppsala University, 75122 Uppsala, Sweden \\ * Correspondence: henrik.scander@oru.se; Tel.: +46-19-302008
}

Citation: Scander, H.; Lennernäs Wiklund, M.; Yngve, A. Assessing Time of Eating in Commensality Research. Int. J. Environ. Res. Public Health 2021, 18, 2941. https:// doi.org/10.3390/ijerph18062941

Academic Editors: Paul B. Tchounwou and Omorogieva Ojo

Received: 27 January 2021

Accepted: 10 March 2021

Published: 13 March 2021

Publisher's Note: MDPI stays neutral with regard to jurisdictional claims in published maps and institutional affiliations.

Copyright: (c) 2021 by the authors. Licensee MDPI, Basel, Switzerland. This article is an open access article distributed under the terms and conditions of the Creative Commons Attribution (CC BY) license (https:// creativecommons.org/licenses/by/ $4.0 /)$.

\begin{abstract}
Commensal meals seem to be related to a better nutritional and metabolic health as well as an improved quality of life. The aim of this paper was to examine to what extent research was performed using the search term commensality related to assessment of timing of meals. A scoping review was performed, where 10 papers were identified as specifically addressing the assessment of timing of commensality of meals. Time use studies, questionnaires, and telephone- and personto-person interviews were used for assessing meal times in relation to commensality. Four of the studies used a method of time use registration, and six papers used interviews or questionnaires. Common meals with family members were the most common, and dinners late at night were often preferred for commensal activities among the working population. In conclusion, the family meal seemed to be the most important commensal meal. It is clear from the collected papers and from previous systematic reviews that more studies of commensal meals in general and about timing aspects in particular and in relation to nutritional health are essential to provide a solid background of knowledge regarding the importance of timing in relation to commensal meals.
\end{abstract}

Keywords: eating together; conviviality; gastronomy; meal; food studies; dining; eating practice

\section{Introduction}

\subsection{Meal Patterns and Grazing}

In human nutrition and sociology, human eating behavior is referred to as eating patterns or meal patterns. Douglas \& Gross (1981) define a meal as "A structured event that is a social occasion which is organized according to rules prescribing time, place and a sequence of actions. If food is taken as a part of the structured event, then we have a meal" [1]. Grazing assumes food is eaten in an incidental manner with respect to time, place, and content, responding to immediate preferences and desires [2]. Within nutritional research, commensality is emphasized as important for supporting nutritional health and food enjoyment $[3,4]$. Increasingly, it is apparent that meal timing must also be considered to ensure optimal health benefits in response to dietary patterns [5]. Moreover, commensality research is also important for an increased understanding of recent changes in dietary habits, social change and stability in the everyday eating [6] and eating out [7].

Does a natural meal pattern exist? In their review article, the authors [8] draw the conclusion that a basic meal pattern over time and culture is three main meals plus two subordinate meals per day. The authors also conclude that regular meals during the day help maintain the biological schedule of a circadian rhythm. In a 24-h society, regularity in living habits is sometimes abandoned due to shift work, jet lag, and social jet lag, and individuals might be active at all hours of the day [8]. An underlying assumption is that a social rhythm in eating that supports and strengthens the biological rhythms in hunger vs. satiation, while satiety promotes health, wellbeing, and optimal energy intake. In addition, commensality might have a supportive role in establishing a daily rhythm in eating. 


\subsection{Family Meals and Other Social Eating}

The relationship between family meals and various nutritional health outcomes is an important research topic in relation to the great importance of healthy eating [9] or in relation to quarantine issues during the Covid-19 pandemic as pointed out by the WHO [10]. Family meals offer a rich opportunity to expose children to healthy foods, where children can learn healthy eating routines and behaviors from an early age [11]. A meta-analysis of the frequency of family meals showed a positive association between frequent family meals and better nutritional health. This was the case in younger and older children, across countries and socioeconomic groups, and for meals taken with the whole family vs. one parent. Regarding these findings, more research is recommended to target the causal direction of the relationship between family meal frequency and nutritional health [11]. The review also stated that most studies had investigated either 'family dinner' or 'family meals' and some to a lesser extent explored 'family breakfast' or 'family lunch'. The authors concluded that the association between meal frequency and nutritional health holds regardless of whether families eat breakfast, lunch or dinner together.

Another review shows the inconsistency in the way in which studies have defined and assessed family meals [12]. The finding emphasized that family meals were associated with a range of positive outcomes among children and adolescents. Most studies used frequency or mean number of family meals per week. Less focus was directed towards different structural features that can also be of importance for family meals, such as who is present, eating place or setting, and how long family meals typically last. These findings provided an initial understanding of the structural features used to define family meals, but the findings also pointed to the importance of developing more comprehensive and sensitive assessment methods that can explain the complexity and multidimensional nature of family meals [12].

Poor health among the elderly and cognitively impaired is often related to a poor quality of life and problems with malnutrition and dehydration, as identified in a review [13]. The structuring of healthy eating and drinking was considered important in supporting healthy life patterns. The review found that studies were very limited, but the authors concluded that eating meals with caregivers, family meals or family style meals, soothing mealtime music, constantly accessible snacks, and longer mealtimes seemed to be promising interventions.

A recent systematic review of the relationship between nutritional behaviors and metabolic indices [14] identified "eating together" as one of the behavioral factors of importance. However, the review concluded that there were too few studies for a good analysis of the importance of eating together and recommended well-structured studies to disentangle links between nutritional behaviors and metabolic indices. Policymaking and the design of social interventions must rely on additional studies.

\subsection{Different Patterns in Activity and Sleep}

The circadian timing system or time-keeping system tells us when to wake up, eat, and go to bed. The "master clock" is the suprachiasmatic nucleus or nuclei (SCN) located directly above the optic chiasm in hypothalamus in the brain. SCN generates neural and hormonal rhythms that affect behavior as well as physiological functions [15]. Human beings, except for newborns, are "monocyclic", which means that the 24-h day includes only two phases: activity and sleep. Exceptions are newborns, having more than one period of activity and sleep. A diminished timing system in the elderly is associated with decreased appetite and loss of thirst due to atrophy in the hypothalamic area. Joint cultural activities such as preparing food and commensality are difficult to maintain when some people work while others are asleep.

Humans may have a preference of waking up late and staying awake at night or waking up and going to bed early. This pattern might refer to their chronotype. A chronotype is the behavioral manifestation of underlying circadian rhythms in physiological processes. The two extremes are eveningness (delayed sleep period, "night owls") and morningness 
(advanced sleep period, "larks") [16]. Most individuals have some flexibility in the timing of their sleep period. Pre-pubescent children and the elderly often prefer waking up early (morningness), while adolescents prefer a delayed sleep period (eveningness). The appearance of different chronotypes within a family is demonstrated when infants, adolescents, parents, and grandparents prefer eating at different times of the day. Timing of family meals requires compromises.

\subsection{Previous Studies of Shift and Night Workers' Commensal Eating}

Natural shifts between daylight and darkness naturally control the human rhythm in activity, sleep, and eating [15]. Travelling across time zones causes jet-lag due to the body's circadian rhythm not being synchronized with the actual local day and night time. Dietary habits are considered a leading behavioral risk factor for human health in general, and there is growing evidence pointing to diet and sleep being related. For example, consumption of healthy foods has been shown to be associated with better sleep quality, while higher intake of processed and sugar rich foods was associated with worse sleep features [17]. The body cannot change the circadian rhythm immediately after moving between time zones for example, the adjustment takes place within a few days. Light, darkness, and social rhythm counteract the adjustment of the circadian rhythm in shift workers, leading to increased risk of a disruption, which is associated with impaired performance and metabolic disorders [18]. Shift workers often suffer from social jet-lag as a result of moving between two time zones: one that is governed by work and social obligations and another that is governed by our biological clock, also called the circadian time [19]. Among the workforce in Europe, 17 percent work shifts and 19 percent have night work [20]. In many studies, shift workers are defined as those who never work regular daytime hours [21]. During the last five decades, the proportion of shift workers has increased [22,23].

In a review, Lowden, A., et al. [23] examined 20 studies on food and nutrition among shift workers. The overview included dietary assessment studies. The results indicated that total energy intake over 24-h did not vary between day and shift workers or between work shifts. The paper presents guidelines for meal timing for shift workers and also general guidelines "provide appropriate dining facilities ( ... ) allow a meal to be eaten away from the workplace, with colleagues, in as pleasant surrounding as possible".

Nicholls et al. (2016) [24] investigated barriers and facilitators to healthy eating for nurses in the work place. Meals were often shared, and conversations about diet and exercise strengthened the motivation to adopt healthier habits. On the other hand, nurses often influenced each other to eat junk food, and social eating practices could involve "treats" such as cakes and pizza.

In a study using quantitative data [25], a longitudinal approach was used to explore the relative role of food-related, personal, and situational factors. The study monitored how 71 participants compiled and experienced 519 meals from their work place buffet during a three-month period. Meal satisfaction was directly associated with a positive ambience. Time available, mindful eating, and eating with close colleagues were positively associated with the perceived ambience. Among the most important factors was the possibility to share the meal with close colleagues.

In a qualitative semi-structured interview study [26], nine Scandinavian flight attendants were interviewed. The working conditions for this professional group often involves extended and irregular working hours, short rest periods, difficulties in planning for breaks, and high demands of service provision. Work schedules can include early shifts and time zone transitions that imply constant exposure to related health risks. Eating took place when food was available and when there was enough time to eat, rather than being guided by hunger and social context. Standing up to eat had almost become a marker of the fact that eating was not perceived as a part of a break. It became a part of a collegial agreement and a collegial act to wait until everyone had completed their working tasks. Eating together was often not possible. 
In connection to performing an earlier scoping review on commensality [27], "time of eating" seemed to be a neglected topic, which is why an expanded search was performed on this topic. Scoping reviews are useful tools in the ever-increasing arsenal of evidence synthesis approaches, and one can conduct scoping reviews instead of systematic reviews where the purpose of the review is to identify knowledge gaps, scope a body of literature, clarify concepts or investigate research conduct (Munn et al., 2018). Therefore, our intent was to perform this scoping review as a precursor to other systematic reviews. This scoping review could serve as an important way to confirm the relevance of the topic and further develop the search methodology.

The aim of this paper was to examine study designs and methods used to assess timing of eating and commensality in studies of eating habits through a scoping review.

\section{Materials and Methods}

We performed a scoping review of papers discussing commensality assessment as a scoping review, mapping the body of a specific topic to summarize and disseminate relevant literature [28]. This scoping review followed the steps suggested by Arksey and O'Malley [29]: (1) identifying the research question, (2) identifying relevant literature, (3) selecting the studies, (4) charting the data, and (5) collating, summarizing and reporting the results. We used the search term commensality and searched the Web of Science Core Collection. Inclusion criteria were:

1. Published up to 19 February 2021.

2. Published in English.

3. Somehow assessing commensality.

4. Describing commensality among humans.

5. Including aspects of timing.

A total of 168 papers were found in a search using the search term commensality. Ten papers were identified that especially discussed time in relation to commensal eating.

\section{Results}

In Table 1 below, the papers are presented in alphabetical order, while in the text we have described them depending on the method used.

\subsection{Time Use Data in Commensality Research}

Three of the studies were performed in Belgium by Mestdag et al. [30-32]. These studies used a method of time-use registration to collect information about commensality. A main feature was the family meal, but other commensal patterns were also researched. Two of these papers point out a substantial decrease of the number of family meals from 1966 to 1999 , and the temporal boundaries of when to eat became more vague over time [30,31]. The authors state that the existence of a structured event in time and place was strongly impacted by the living arrangements and the move towards smaller households. Furthermore, cohabiting children were still having meals with their parents in 1999. A third study [32] questioned to what extent the role of the family meal was a reference point for shaping our eating habits. In a comparison of two Flemish time-use studies, from 1988 to 1999, the authors concluded that eating habits are highly structured events and are characterized as a social occasion. A Korean study, using a time-use survey pointed to an increase in social meals, often seemingly stretched out over time and including others than the close family [33].

\subsection{Studies Using Questionnaires or Interviews on Commensality Research}

Commensality in Japan was studied using face-to-face interviews [34]. This study showed that family commensality varied by co-habitation and time schedules for participants. The authors found no association between family meal frequency and household size. The study also showed that retired couples were able to eat common meals more frequently, while full-time employment made it more difficult to have commensal dinners 
on weekdays. The Japanese goal of having a family breakfast or dinner more than 11 times per week was demonstrated to be difficult to reach, especially among working people and non-nuclear families.

Three studies involved comparisons of routines over two cultures, one regarding FrenchBritish couples [35], the other two the cities of Santiago, Chile, and Paris, France [36,37]. The interview study on French and British couples revealed that the timing of dinners appeared to move against the temporal preference of the country of residence. The French in Britain particularly missed the lunch commensality that takes place much more between colleagues in France. The two Santiago-Paris studies performed through semi-structured questionnaires both showed that synchronicity of meals was positively influenced by the presence of others outside the close family circle and that dinner time needed some synchronization effort to create commensality, even within the family.

A British study was performed as an online survey presented to a sample of a consumer panel [38]. Older and more affluent, well-educated consumers were overrepresented. The study showed that eating with household members was the most common commensal event. The authors also stated that even those living with others often ate alone. Weekends and evenings provided proof of more sociability at meals, while work meals were preferably eaten with colleagues.

A study from a Danish research group used two cross-sectional surveys performed in 1997 and 2012 in four Nordic countries [39]. The authors used telephone-based interviews or an internet-based questionnaire plus a $24-\mathrm{h}$ recall to collect data on dietary quality. These dietary data provide a more realistic actual intake rather than the usual intake often used in research. This study showed some differences in regards to meal frequency, commensality, and meal composition from 1997 to 2012, but the differences were not the same in all four countries. More solitary meals and quick meals could be traced in some of the countries. The home and the workplace were the most frequent places for eating. Using phones and other electronic devices while eating was frequent in 2012, as well as eating in front of the TV. Living alone made a big difference in the increased number of commensal events. Dinner was the meal most likely to be enjoyed in company and took more time, even though sometimes eaten in front of a TV. The authors recommended the use of mixed methods, including more qualitative data from interviews, observations or open question surveys in order to arrive at a more comprehensive understanding of commensal eating as a whole and its importance for healthy choices.

Making dietary surveys, one can use those that cover the "usual intake" such as using more or less complicated food frequency questionnaires (FFQ) with questions such as "how often do you eat certain foods?" The "actual intake" can be studied by methods where the research persons register their eating in a diary, sometimes using a scale or camera to document intake. They can also be interviewed about what they ate and drank during the last $24 h$, or complete a questionnaire on what they ate and drank yesterday, sometimes with indications on when, where. The latter methods showing actual intake are more reliable than the FFQ's usual intake, which becomes more vague and relies on memory. [40,41]. 
Table 1. Summary of the reviewed studies $(n=10)$ : Time and Space.

\begin{tabular}{|c|c|c|c|c|c|}
\hline $\begin{array}{l}\text { Authors (Year), } \\
\text { Country }\end{array}$ & Objectives & $\begin{array}{l}\text { Study Design and } \\
\text { Participants }\end{array}$ & Method & Results/Discussion & $\begin{array}{l}\text { Results in Relation to } \\
\text { the Review }\end{array}$ \\
\hline $\begin{array}{l}\text { Darmon \& Warde (2019) } \\
\text { [35] UK "Habits and } \\
\text { orders of everyday life: } \\
\text { commensal adjustment } \\
\text { in Anglo-French } \\
\text { couples". }\end{array}$ & $\begin{array}{l}\text { This paper examines } \\
\text { processes of habit } \\
\text { reshuffling and change } \\
\text { in different contexts of } \\
\text { household formation, } \\
\text { looking specifically at } \\
\text { habits regarding eating } \\
\text { and commensality. }\end{array}$ & $\begin{array}{l}\text { An interview study of } \\
14 \text { couples, each with } \\
\text { one English and one } \\
\text { French partner, half of } \\
\text { whom live in France, } \\
\text { half in England. }\end{array}$ & $\begin{array}{l}\text { Interviewed couples } \\
\text { together about their } \\
\text { current eating habits, } \\
\text { with follow-up } \\
\text { interviews. }\end{array}$ & $\begin{array}{l}\text { Making arrangements } \\
\text { to eat together is one of } \\
\text { the most fundamental } \\
\text { and general facets of } \\
\text { setting up a new } \\
\text { household in Western } \\
\text { societies. The } \\
\text { importance of } \\
\text { commensality for } \\
\text { couples and families is } \\
\text { widely recognized. The } \\
\text { French particularly } \\
\text { missed meals at lunch } \\
\text { time, typically eaten } \\
\text { with colleagues in } \\
\text { France, but the biggest } \\
\text { problems of adjustment } \\
\text { for the migrant } \\
\text { involved the rituals and } \\
\text { timing of the } \\
\text { commensal meals. }\end{array}$ & $\begin{array}{l}\text { Showing how habits are } \\
\text { scripted in three } \\
\text { different orders of } \\
\text { everyday life, } \\
\text { governing diets, meal } \\
\text { times, and } \\
\text { extra-domestic } \\
\text { commensality. The } \\
\text { temporal and sociability } \\
\text { orders appear to be } \\
\text { geared to much firmer } \\
\text { principles, governing } \\
\text { performances in a more } \\
\text { unified and 'sticky' way, } \\
\text { and scripting more } \\
\text { 'solid' incorporated } \\
\text { habits, for both } \\
\text { countries, where the key } \\
\text { principles are the } \\
\text { centrality of meal times } \\
\text { and the table, to the } \\
\text { collective time } \\
\text { organization of the } \\
\text { country of residence } \\
\text { and the commensal and } \\
\text { ritualized events. }\end{array}$ \\
\hline $\begin{array}{l}\text { Giacoman et al. (2021) } \\
\text { [36] Chile and France } \\
\text { "Meal synchronization } \\
\text { and commensality in } \\
\text { Santiago and Paris". }\end{array}$ & $\begin{array}{l}\text { This article analyzes the } \\
\text { association between } \\
\text { meal synchronization } \\
\text { and commensality } \\
\text { using representative } \\
\text { survey data in Santiago } \\
\text { and Paris. }\end{array}$ & $\begin{array}{c}\text { Empirical material is } \\
\text { drawn from two } \\
\text { comparable data } \\
\text { sources: Encuesta de } \\
\text { Comensalidad en Adultos } \\
\text { de la Región } \\
\text { Metropolitana (Santiago, } \\
\text { Chile) and Santé, } \\
\text { Inégalités et Ruptures } \\
\text { Sociales (Paris, France). }\end{array}$ & $\begin{array}{l}\text { Santiago data: the } \\
\text { survey was a } \\
\text { semi-structured } \\
\text { questionnaire about } \\
\text { opinions and declared } \\
\text { practices on } \\
\text { commensality and } \\
\text { sociodemographic } \\
\text { characteristics, with a } \\
\text { self-administered diary } \\
\text { detailing all eating } \\
\text { events. For Paris, the } \\
\text { cohort study was a } \\
\text { three-level random } \\
\text { sample questionnaire. }\end{array}$ & $\begin{array}{l}\text { In both metropolises, } \\
\text { sharing meals with } \\
\text { others more frequently } \\
\text { was positively } \\
\text { associated with having } \\
\text { meals in synchronized } \\
\text { timeslots. Next, we } \\
\text { found differences } \\
\text { between Santiago and } \\
\text { Paris. In Paris, } \\
\text { commensality was } \\
\text { associated with } \\
\text { synchronization in all } \\
\text { three shared timeslots, } \\
\text { and in Santiago, in the } \\
\text { midday and the evening } \\
\text { slots. }\end{array}$ & $\begin{array}{l}\text { Sharing meals was } \\
\text { positively associated } \\
\text { with having meals at } \\
\text { synchronized times. } \\
\text { Enacting the social } \\
\text { norm of eating on a } \\
\text { regular schedule is } \\
\text { likely to be influenced } \\
\text { by the presence of } \\
\text { others. Sharing a meal } \\
\text { with others needs } \\
\text { synchronization and } \\
\text { facilitates the enactment } \\
\text { of social norms around } \\
\text { eating times. }\end{array}$ \\
\hline $\begin{array}{l}\text { Holm, L et al. (2016) } \\
\text { [39] Changes in the } \\
\text { social context and } \\
\text { conduct of eating in } \\
\text { four Nordic countries } \\
\text { between } 1997 \text { and } 2012 .\end{array}$ & $\begin{array}{l}\text { Analyzes changes in the } \\
\text { social organization of } \\
\text { eating in four Nordic } \\
\text { countries 1997-2012 }\end{array}$ & $\begin{array}{c}\text { Four Nordic countries, } \\
\text { Denmark, Finland, } \\
\text { Norway and Sweden. } \\
4808 \text { individuals aged } \\
15 \text { and older, } 20128248 \\
\text { individuals } 15-80 \text { years } \\
\text { of age }\end{array}$ & $\begin{array}{l}\text { Two cross-sectional } \\
\text { surveys, including the } \\
\text { 24-h recall method. } \\
\text { While the } 1997 \text { survey } \\
\text { was based on } \\
\text { computer-assisted } \\
\text { telephone interviews, } \\
\text { the } 2012 \text { survey was } \\
\text { based on an } \\
\text { internet-based } \\
\text { questionnaire. }\end{array}$ & $\begin{array}{l}\text { Some differences were } \\
\text { seen between } 1997 \text { and } \\
\text { 2012, but these were not } \\
\text { consistent between } \\
\text { countries. No dramatic } \\
\text { changes in the social } \\
\text { organization of eating } \\
\text { on the whole. }\end{array}$ & $\begin{array}{l}\text { Possibly a slacking of } \\
\text { eating etiquette has } \\
\text { taken place. In addition, } \\
\text { more solitary meals and } \\
\text { eating quickly; meals } \\
\text { could be traced over the } \\
\text { years in some countries. } \\
\text { Using the 24-h recall } \\
\text { method when collecting } \\
\text { the data was considered } \\
\text { giving a truer picture of } \\
\text { the events rather than a } \\
\text { general question of } \\
\text { "usual" habits. } \\
\text { Recommended use of a } \\
\text { mixed-methods } \\
\text { methodology including } \\
\text { more qualitative data in } \\
\text { parallel with the } 24-h \\
\text { recall. }\end{array}$ \\
\hline
\end{tabular}


Table 1. Cont.

\begin{tabular}{|c|c|}
\hline $\begin{array}{l}\text { Authors (Year), } \\
\text { Country }\end{array}$ & Objectives \\
\hline $\begin{array}{l}\text { Kim (2020) [33] South } \\
\text { Korea "Solitary eating, } \\
\text { an inferior alternative? } \\
\text { An examination of } \\
\text { time-use data in South } \\
\text { Korea". }\end{array}$ & $\begin{array}{l}\text { This study had two } \\
\text { objectives: (1) to } \\
\text { investigate the changes } \\
\text { in the frequency, } \\
\text { duration, and timing of } \\
\text { solitary, family, and } \\
\text { social meals in South } \\
\text { Korea and (2) to } \\
\text { examine the effects of } \\
\text { these meals on } \\
\text { subjective well-being. }\end{array}$ \\
\hline
\end{tabular}

$\begin{array}{cc}\begin{array}{c}\text { Study Design and } \\ \text { Participants }\end{array} & \text { Method } \\ & \\ & \\ & \text { Two-day time-diary } \\ & \text { survey in which } \\ & \text { respondents were asked } \\ \text { Data from the Korean } & \text { record their activities } \\ \text { Time Use Survey, } & \text { in a time diary } \\ \text { conducted by the Korea } & \text { consisting of 144 } \\ \text { National Statistical } & \text { ten-minute time slots. } \\ \text { Office every five years } \\ \text { since 1999, analyzed in } \\ \text { regards to meals. }\end{array} \quad \begin{gathered}\text { The nationally } \\ \text { representative sample } \\ \text { varied in size across the } \\ \text { four surveys. }\end{gathered}$

Results/Discussion
South Koreans spent
83.8 min eating 2.69
meals on a typical
weekday in 2014. The
most noticeable change
regarded family meals,
which rapidly declined
in both frequency (from
$54.6 \%$ in 1999 to $39.8 \%$
in 2014 ) and total
duration (from $53.6 \%$ to
$38.4 \%$ ). Solitary and
social meals, on the
other hand, showed
substantial increases
between 2004 and $2014 ;$
the former was
conspicuous in its
frequency, while the
latter in length.

Results in Relation to the Review

The shared family meal

has declined rapidly in both frequency and

duration. The increase

in social meals explains why South Koreans spend more time eating, despite the declining frequency of meals. One explanation is that social gatherings in South Korea have increasingly involved eating and that the respondents reported the eating part of such socializing as time spent eating.

Highlighted cross-metropolitan similarities and disparities, regarding meal times and

Investigation of meal schedules and their social determinants in order to question to what extent mealtimes are still socially shared events and what social institutions still shape national eating schedules.
Two comparable data sources: Encuesta de Comensalidad en Adultos de la Región

Metropolitana (Santiago,

Chile) and Santé,

Inégalités et Ruptures

Sociales (Paris, France),

used to investigate meal schedules.
Cohort study representative of the adult $(\geq 18)$ population in Paris and a survey representative of the adult $(\geq 18)$ population living in the Santiago. Paris (France)".

To investigate what (2005) [30] Belgium "Where has family time gone? In search of joint family activities and the role of the family meal in 1966 and 1999"
Time-use data used to study meal timing.

Study 1965: 2077 Belgians 19-65 years; $\begin{array}{ll}\text { family time. } & \text { Study 1998-2000: } 8392 \\ \text { Belgians 12-95 years }\end{array}$ old.
Registration of time-use Two Belgia time-budget studies. Study I: one 24-h diary. Study II: One 24-h dairy during the working day and one 24-h diary for Saturday or Sunday. Diaries reported the total time spent on the most important family activities and meals as $\%$ of the total time of each activity. In addition, family meal timing was studied. synchronization. Both metropolises shared a similar and marked three-meal pattern.

Three major peaks

distributed throughout

the day correspond to

breakfast, lunch, and

dinner. Lunch was more

synchronized than dinner, for reasons pertaining to

professional and school rhythms. Dinner,

however, demonstrated an important

coordination effort towards the

synchronization of social time within the family.

Time spent eating with partners and children were as follows in 1966 and 1999 (h, $\mathrm{min}$ ): Workdays $0,51 / 0,27$, Saturdays 1,05/1,03, Sundays 1, 23/1,05. Family time of day for meals peaked around 8 am, $1 \mathrm{pm}$, and $8 \mathrm{pm}$ during working days, although fewer respondents were

Collective mealtimes can be partly understood with regard national specificities. If meal time is tied to the constraints of social and professional life, it also expresses many other dimensions of the meal, including commensality. A comparison also highlighted important disparities between the two metropolises regarding meal schedules and synchronization.

Family time spent was predominantly used for sharing meals. The number of commensal occasions with partners and children declined from 1966 to 1999; still, eating on every day of the week is the social par excellence for keeping up with the engaged in family meals 1999. Working days: family activities took place around eating times. Traditional meal times lost importance during 30 years. In 1999, meals were served later and fewer parents spent time with children at breakfast. latest news and events of other family members. One

underlying question is if family meals set the rhythm of family life. 
Table 1. Cont.

\begin{tabular}{|c|c|c|c|c|c|}
\hline $\begin{array}{l}\text { Authors (Year), } \\
\text { Country }\end{array}$ & Objectives & $\begin{array}{l}\text { Study Design and } \\
\text { Participants }\end{array}$ & Method & Results/Discussion & $\begin{array}{l}\text { Results in Relation to } \\
\text { the Review }\end{array}$ \\
\hline $\begin{array}{c}\text { Mestdag \& Glorieux } \\
\text { (2009) [31] Belgium } \\
\text { "Change and stability in } \\
\text { commensality patterns: } \\
\text { a comparative analysis } \\
\text { of Belgian time-use data } \\
\text { from 1996, } 1999 \text { and } \\
\text { 2004" }\end{array}$ & $\begin{array}{l}\text { To assess how } \\
\text { commensality patterns } \\
\text { have evolved in } \\
\text { Belgium over the last } \\
\text { decades and which } \\
\text { factors have an impact } \\
\text { on commensality. }\end{array}$ & $\begin{array}{l}\text { The Belgian time-use } \\
\text { survey 1966: } 2076 \\
\text { Belgians, 19-65 years. } \\
\text { 1999: The 2nd National } \\
\text { Belgian time-use survey } \\
8382 \text { Belgians, 12-95 } \\
\text { years, from } 4 \text { 275 } \\
\text { households used to } \\
\text { study commensal } \\
\text { meals. }\end{array}$ & $\begin{array}{l}\text { Time-use data of daily } \\
\text { practices by use of a } \\
\text { self-completion } \\
\text { procedure using 10-min } \\
\text { intervals. Two Belgian } \\
\text { time-budget studies } \\
\text { from } 1966 \text { and } 1999 . \\
\text { One 24-h diary (1966) } \\
\text { and one diary during } \\
\text { the working day and } \\
\text { one 24-h diary for } \\
\text { Saturday or Sunday } \\
\text { (1999) Time data (2004) } \\
\text { were used to determine } \\
\text { the factors that affect } \\
\text { commensality. }\end{array}$ & $\begin{array}{l}\text { Average time spent on } \\
\text { eating and relative share } \\
\text { of total eating time on } \\
\text { weekdays, Saturdays or } \\
\text { Sundays, according to } \\
\text { social context were } \\
\text { reported. There was a } \\
\text { significant decrease in } \\
\text { commensality during } \\
\text { the period: eating } \\
\text { became more } \\
\text { individualized. In 1966, } \\
73 \% \text { of weekday eating } \\
\text { time occurred with at } \\
\text { least one household } \\
\text { member present, as } \\
\text { compared to } 56 \% \text { in } \\
1999 .\end{array}$ & $\begin{array}{l}\text { Living arrangements } \\
\text { had the strongest } \\
\text { impact on } \\
\text { commensality patterns. } \\
\text { People who lived alone } \\
\text { generally do not have } \\
\text { anyone with whom they } \\
\text { shared their meals. } \\
\text { Married and cohabitant } \\
\text { couples ate together on } \\
\text { a regular basis; parents } \\
\text { still shared a majority of } \\
\text { meal times with their } \\
\text { co-resident children. }\end{array}$ \\
\hline $\begin{array}{l}\text { Mestdag, I. (2005) [32] } \\
\text { “Disappearance of the } \\
\text { traditional meal: } \\
\text { Temporal, social and } \\
\text { spatial destruction.” }\end{array}$ & $\begin{array}{l}\text { To study the } \\
\text { disappearance of the } \\
\text { "traditional" meal by } \\
\text { comparing Flemish time } \\
\text { budget data for } 1988 \\
\text { and 1999. Temporal, } \\
\text { social, and spatial } \\
\text { features of the meal } \\
\text { were studied. }\end{array}$ & $\begin{array}{l}\text { Flemish time budget } \\
\text { data were used to study } \\
\text { meal features. In 1988, } \\
463 \text { respondents } 21-40 \\
\text { years, in } 1999,599 \\
\text { respondents. }\end{array}$ & $\begin{array}{l}\text { In 1988, respondents } \\
\text { kept a diary for three } \\
\text { consecutive days. In } \\
\text { 1999, respondents } \\
\text { followed the same } \\
\text { procedure for one week. } \\
\text { All activities including } \\
\text { timing, duration, and } \\
\text { location were registered. } \\
\text { Respondents completed } \\
\text { a questionnaire. }\end{array}$ & $\begin{array}{l}\text { Flemish eating practices } \\
\text { showed a high level of } \\
\text { structure in the } \\
\text { temporal, spatial, and } \\
\text { organization of the meal. } \\
\text { A clear three-meal } \\
\text { pattern: breakfast, } \\
\text { lunch, and dinner was } \\
\text { observed both } 1988 \text { and } \\
\text { 1999. The temporal } \\
\text { boundaries of eating } \\
\text { became vague, people } \\
\text { ate less frequently at } \\
\text { traditional meal times, } \\
\text { the number or real } \\
\text { meals decreased, and } \\
\text { the number of informal } \\
\text { snacks increased; } \\
\text { indicators of temporal } \\
\text { destruction were found. }\end{array}$ & $\begin{array}{l}\text { The meals became } \\
\text { shorter and solitary } \\
\text { eating increased. Eating } \\
\text { at home decreased in } \\
\text { importance. In the } \\
\text { introduction to the } \\
\text { study, the following } \\
\text { was discussed; a meal is } \\
\text { when food is taken as a } \\
\text { part of a structured } \\
\text { event prescribing the } \\
\text { time, place, and } \\
\text { sequence of actions. } \\
\text { Grazing assumes that } \\
\text { food is taken in an } \\
\text { incidental manner with } \\
\text { respect to time, place, } \\
\text { and content. It is } \\
\text { unclear if the family } \\
\text { meal still operates as a } \\
\text { reference point in } \\
\text { shaping eating habits. }\end{array}$ \\
\hline $\begin{array}{c}\text { Takeda, W., et al. (2018). } \\
\text { [34] “Who eats with } \\
\text { family and how often? } \\
\text { Household members } \\
\text { and work styles } \\
\text { influence frequency of } \\
\text { family meals in urban } \\
\text { Japan." }\end{array}$ & $\begin{array}{l}\text { To examine frequencies } \\
\text { of family commensality } \\
\text { meals and the } \\
\text { socio-cultural } \\
\text { organization of eating } \\
\text { and family lives. }\end{array}$ & $\begin{array}{l}\text { Japanese adults aged } \\
20-85 \text { years in two } \\
\text { metropolitan areas } \\
\text { between } 2009 \text { and } 2013 \\
\text { were interviewed } \\
\text { regarding meals, } \\
\text { including times. Lay } \\
\text { people } \mathrm{N}=179 \text { and } \\
\text { dietitians }(\mathrm{N}=63) .\end{array}$ & $\begin{array}{c}242 \text { surveys } \\
\text { administered in } \\
\text { face-to-face interviews } \\
\text { in Tokyo and Kyoto. } \\
\text { Interviews including } \\
\text { open-ended free-list } \\
\text { questions followed the } \\
\text { mostly quantitative } \\
\text { survey questions. } \\
\text { Reports about usual } \\
\text { meal times on working } \\
\text { days and weekend } \\
\text { days. }\end{array}$ & $\begin{array}{l}\text { Peak weekday meal } \\
\text { times: } 7.00-7.59 ; \\
\text { 12.00-12.59; } 19.00-19.59 \text {. } \\
\text { Frequencies of family } \\
\text { commensality are } \\
\text { influenced by } \\
\text { co-residents and work } \\
\text { styles of participants } \\
\text { rather than household } \\
\text { sizes. Meal frequencies } \\
\text { for family commensality } \\
\text { were highest among } \\
\text { those er } 60 \text { for all meals. }\end{array}$ & $\begin{array}{l}\text { Work and lifestyle } \\
\text { constraints impacting } \\
\text { schedules appear to } \\
\text { influence the frequency } \\
\text { of family commensality. } \\
\text { The Japanese } \\
\text { government has } \\
\text { promoted family } \\
\text { commensality and set a } \\
\text { goal; family breakfast } \\
\text { and dinner more than } 11 \\
\text { times per week. There } \\
\text { were substantive gaps } \\
\text { between the promoted } \\
\text { image of family } \\
\text { commensality and the } \\
\text { practical and structural } \\
\text { complaints on achieving } \\
\text { family commensality, } \\
\text { especially among } \\
\text { working people and } \\
\text { non-nuclear families. } \\
\text { Full time workers had } \\
\text { the latest average } \\
\text { dinner time. }\end{array}$ \\
\hline
\end{tabular}


Table 1. Cont.

\begin{tabular}{|c|c|c|c|c|c|}
\hline $\begin{array}{l}\text { Authors (Year), } \\
\text { Country }\end{array}$ & Objectives & $\begin{array}{l}\text { Study Design and } \\
\text { Participants }\end{array}$ & Method & Results/Discussion & $\begin{array}{c}\text { Results in Relation to } \\
\text { the Review }\end{array}$ \\
\hline $\begin{array}{l}\text { Yates L, Warde A. (2017) } \\
\text { [38] Eating together and } \\
\text { eating alone: meal } \\
\text { arrangements in British } \\
\text { households. }\end{array}$ & $\begin{array}{c}\text { Examined meal } \\
\text { arrangements in British } \\
\text { households in 2012, } \\
\text { drawing on an online } \\
\text { survey in the format of a } \\
\text { food diary administered } \\
\text { to } 2784 \text { members of a } \\
\text { supermarket consumer } \\
\text { panel. }\end{array}$ & $\begin{array}{l}\text { Investigating aspects of } \\
\text { British meal patterns, } \\
\text { provisioning and } \\
\text { preparation, timing, and } \\
\text { commensality. Online } \\
\text { survey on meal } \\
\text { arrangements }\end{array}$ & $\begin{array}{l}\text { A small sample drawn } \\
\text { from a consumer panel } \\
\text { associated with a } \\
\text { supermarket loyalty } \\
\text { card scheme. The } \\
\text { sample was } 2784 \\
\text { individuals, i.e., a } 45 \% \\
\text { response rate. Older, } \\
\text { more affluent, better } \\
\text { educated respondents } \\
\text { and respondents } \\
\text { without children were } \\
\text { overrepresented. }\end{array}$ & $\begin{array}{l}\text { Household members } \\
\text { were the most common } \\
\text { source of } \\
\text { companionship in } \\
\text { meals }(75 \%) \text { vs. work } \\
\text { colleagues }(16 \%) .\end{array}$ & $\begin{array}{l}\text { Meals taking place later } \\
\text { in the day were more } \\
\text { likely to be eaten in } \\
\text { companionship. Foods } \\
\text { eaten with others are, } \\
\text { for example, roasts, } \\
\text { curry, fry-ups. When } \\
\text { singles ate alone they } \\
\text { were less likely to have } \\
\text { substantial dishes than } \\
\text { those who live with } \\
\text { others but were eating } \\
\text { alone. Adult-only } \\
\text { households were } \\
\text { underrepresented in } \\
\text { this sample. }\end{array}$ \\
\hline
\end{tabular}

\section{Discussion}

Time-use studies, questionnaires, telephone- and person-to-person interviews were used for assessing meal times in relation to commensality. Commensality on weekday evenings was often hindered by fulltime employment, and commensal meals were often late in the evening. Commensal meals were often the result of planning and negotiation and sometimes even compromise regarding what to eat and when to eat.

\subsection{Time-Use Studies}

We found time-use studies from Belgium and Korea that took into account meal times and commensality patterns [30-33]. Time-use studies are often used in interdisciplinary research trying to identify how people allocate their time. Two National time-use surveys from the UK and the US, did not discuss commensality in their surveys [42,43], even though the US survey looked at time spent eating and in a particular wellbeing module asked about the feelings during that eating time. A National Swedish time-use survey incorporated lunch in the working hours, and the time after work was not specified for different chores or activities [44]. The time-use study method provides a clear picture of what happens during the day and can also outline sleeping habits in relation to time for breakfast, which then accentuates the possibilities for, for example, a family breakfast.

\subsection{Studies Using Questionnaires or Interviews}

Two studies compared results from commensality in different countries, with surveys in Santiago, Chile, and Paris, France [36,37]. Another study interviewed couples originating from France and the UK [35]. These types of cross-cultural studies are of immense importance in the current international community and can also be used to further understand differences between nationalities and ethnic groups in regards to meal times and related to commensality. Of course, etiquette in relation to timing of meals is of importance when hosting multicultural events or political dinners or meals in relation to business meetings, and a lot of effort is often put into these events [45]. This type of cross-cultural study provides a glimpse of important results that can be used for furthering our knowledge on commensality and meal timing etiquette in different cultures.

The Japanese study [34] based on face-to-face interviews showed that the national goal set for family meals at 11 per week, was almost impossible to reach. The fact that the Japanese government has promoted family commensality to such an extent that they have set a national goal for family breakfast and dinner is remarkable and would warrant further research for its applicability and usefulness in order to use it in other nations' dietary guidelines.

The two remaining studies identified in this scoping review were very much alike $[38,39]$, looking at adult eating habits, comparing two studies over time, and including an assessment of dietary quality. Both studies suffered from non-response problems, providing a sample 
which was skewed towards higher educated or in general, socio-economically more privileged groups. The British study [38] showed that commensal meals were about four times as common with household members compared to eating with colleagues. The study of the Nordic countries [39] showed that dinners were the most common meal eaten together. Over time, in some Nordic countries, there was a tendency for more solitary meals and more quick meals. Living alone made a big difference to the number of commensal meals [39], which has been shown in several previous studies [46]. It is important to note that largescale dietary surveys seldom take the opportunity to collect data on meal time or on commensality $[43,44,47]$. In previous studies from the workplace setting, eating together was mostly seen as a healthy eating behavior [24]. It was seen as important to negotiate meal break times with other colleagues, it was seen as a part of a collegial agreement and collegial act to wait until everyone had completed their working tasks [26]. Time available, mindful eating, and eating with colleagues were positively associated with commensal meals and were improved by a positively perceived ambience $[25,36,37]$.

\subsection{Aspects of Circadian Rhythm, Shift/Night Work, and When to Eat}

Aspects of circadian rhythm or shift/night work and their relation to commensal eating were not mentioned in the ten papers identified by the search word commensality. This lack of research on the combined search terms is surprising especially due to the current interest in sleep as a main determinant of health [17]. The chronotypes of individuals in the family or extended family or factors related to shift and night work can be of importance for the negotiation of common meals. The time point for eating as well as for commensality are thus seldom covered in time-use studies or nutritional surveys. Guidelines on the time point for eating can be used to prevent obesity and metabolic disease $[18,19]$.

Commensality at the workplace has a potential for increasing connection between work colleagues and to create an increased satisfaction with the work environment [25]. In studies of workplace meals during normal working hours as well as in shift work, several issues should be considered, including the time point, venue, and content of the meal, as well as the social context [23]. This type of research can provide a good background for health-promoting strategies in work place settings [24]. Commensality during shift work can have an important function when it comes to reducing tiredness during late night hours. Commensality and guidelines on the time point for food breaks and regular meal patterns can be strengthened by an increased knowledge of the biological rhythm of the human metabolism during odd hours.

\subsection{Strengths and Weaknesses of This Study and Suggestions for Future Research}

This study used the search term commensality, which means that a number of studies that used other terms were not included. We could also conclude that the term commensality was not commonly used among researchers specifically studying timing for common meals. The strength of the study was that we used all papers found in the Web of Science Core Collection, which is a high-quality database that includes peer-reviewed papers from several different disciplines. We also did not limit the time for publication other than that the papers had to be published by February 2021. This paper is included in a project collection using a multi-disciplinary view of commensality [48].

In order to come up with scientifically trustworthy results, many more studies of good quality are needed to build a solid base for intervention design as well as for use when formulating policies and guidelines on commensal meal planning. Suggestions for future research could be, for example, the inclusion of timing as an aspect of commensal eating, performing many more high-quality studies, and preferably using a mixed-method including aspects of dietary quality as well as sociological and anthropological components. Studies of compromises for timing of meals could provide important information for guidelines, for example when it comes to late dinners due to work hours or other constraints or when studying commensal breakfasts over generational barriers with different chronotypes. Using the word commensality as a key word would ensure inclusion in studies of 
commensality. Since the studies identified in this scoping review came from Europe, South America and Japan, it seems as if the term has not been widely used in other parts of the world, at least not in studies also focusing on the time point of commensality. Aspects of circadian rhythm, shift work, and night work should be included in studies of common meals, including negotiating techniques for increasing the possibility of attendance of all generations or professionals. The inclusion of commensality and timing of meals in already ongoing large time-use studies and nutrition surveys would be easy and would provide valuable information. The use of good sampling methods is important to obtain a good view of sociodemographic factors, since many previous studies have a tendency of being skewed towards higher education, affluent, and older individuals.

\section{Conclusions}

Time-use studies in general as well as dietary surveys could easily introduce simple questions on commensality. The family meal seems to be the most important commensal meal, depending to a great extent on living arrangements. It is clear from the collected papers and from previous systematic reviews that more studies in the area of timing for commensal meals in relation to health are needed. In a number of studies looking at timing of meals collected in the introduction of this paper, the term commensality was not used. It would be of importance to perform a more comprehensive study using several search terms for commensal eating.

Author Contributions: Conceptualization, H.S., M.L.W. and A.Y. Methodology H.S., M.L.W. and A.Y. Formal analysis H.S., M.L.W. and A.Y. Writing-original draft preparation H.S. and M.L.W., writing-review and editing, H.S. and A.Y. All authors have read and agreed to the published version of the manuscript.

Funding: The publication fee of this open access paper was funded by a generous contribution from the Centre for Integrated Research on Culture and Society (CIRCUS), Uppsala University.

Institutional Review Board Statement: Not Applicable.

Informed Consent Statement: Not Applicable.

Data Availability Statement: Not Applicable.

Conflicts of Interest: The authors declare no conflict of interest.

\section{References}

1. Douglas, M.; Gross, J. Food and culture: Measuring the intricacy of rule systems. Soc. Sci. Inf. 1981, 20, 1-35. [CrossRef]

2. Kjærnes, U. Eating Patterns: A Day in the Lives of Nordic Peoples; National Institute for Consumer Research: Oslo, Norway, 2001.

3. Fischler, C. Commensality, society and culture. Soc. Sci. Inf. 2011, 50, 528-548. [CrossRef]

4. Vesnaver, E.; Keller, H.H. Social influences and eating behavior in later life: A review. J. Nutr. Gerontol. Geriatr. 2011, 30, 2-23. [CrossRef]

5. Hutchison, A.T.; Heilbronn, L.K. Metabolic impacts of altering meal frequency and timing—Does when we eat matter? Biochimie 2016, 124, 187-197. [CrossRef]

6. Gronow, J.; Holm, L. Everyday Eating in Denmark, Finland, Norway and Sweden: A Comparative Study of Meal Patterns 1997-2012; Bloomsbury Academic: London, UK, 2019.

7. Warde, A.; Paddock, J.; Whillans, J. The Social Significance of Dining Out. A Study of Continuity and Change, 1st ed.; Manchester University Press: Manchester, UK, 2020. [CrossRef]

8. Garaulet, M.; Madrid, J.A. Chronobiological aspects of nutrition, metabolic syndrome and obesity. Adv. Drug Deliv. Rev. 2010, 62, 967-978. [CrossRef] [PubMed]

9. Takeda, W.; Melby, M.K.; Ishikawa, Y. Food education for whom?: Perceptions of food education and literacy among dietitians and laypeople in urban Japan. Food Stud. Interdiscip. J. 2017, 7, 49-66. [CrossRef]

10. World Health Organization. Food and Nutrition Tips during Self-Quarantine; World Health Organization: Geneva, Switzerland, 2020.

11. Dallacker, M.; Hertwig, R.; Mata, J. The frequency of family meals and nutritional health in children: A meta-analysis. Obes. Rev. 2018, 19, 638-653. [CrossRef] [PubMed]

12. McCullough, M.B.; Robson, S.M.; Stark, L.J. A Review of the Structural Characteristics of Family Meals with Children in the United States. Adv. Nutr. 2016, 7, 627-640. [CrossRef] [PubMed] 
13. Bunn, D.K.; Abdelhamid, A.; Copley, M.; Cowap, V.; Dickinson, A.; Howe, A.; Killett, A.; Poland, F.; Potter, J.F.; Richardson, K.; et al. Effectiveness of interventions to indirectly support food and drink intake in people with dementia: Eating and Drinking Well IN dementiA (EDWINA) systematic review. BMC Geriatr. 2016, 16, 89. [CrossRef] [PubMed]

14. Nouriyengejeh, S.; Seyedhoseini, B.; Kordestani-Moghadam, P.; Pourabbasi, A. The study of relationship between nutritional behaviors and metabolic indices: A systematic review. Adv. Biomed. Res. 2020, 9, 66. [CrossRef]

15. Bollinger, T.; Schibler, U. Circadian rhythms-From genes to physiology and disease. Swiss Med. Wkly. 2014, 144, w13984. [CrossRef] [PubMed]

16. Adan, A.; Archer, S.N.; Hidalgo, M.P.; Di Milia, L.; Natale, V.; Randler, C. Circadian Typology: A Comprehensive Review. Chronobiol. Int. 2012, 29, 1153-1175. [CrossRef]

17. Godos, J.; Grosso, G.; Castellano, S.; Galvano, F.; Caraci, F.; Ferri, R. Association between diet and sleep quality: A systematic review. Sleep Med. Rev. 2021, 57, 101430. [CrossRef]

18. Asher, G.; Sassone-Corsi, P. Time for food: The intimate interplay between nutrition, metabolism, and the circadian clock. Cell 2015, 161, 84-92. [CrossRef]

19. Maury, E. Off the clock: From circadian disruption to metabolic disease. Int. J. Mol. Sci. 2019, 20, 1597. [CrossRef] [PubMed]

20. Eurofound. Fifth European Working Conditions Survey; Eurofound: Loughlinstown, Ireland, 2012.

21. Esquirol, Y.; Bongard, V.; Mabile, L.; Jonnier, B.; Soulat, J.M.; Perret, B. Shift work and metabolic syndrome: Respective impacts of job strain, physical activity, and dietary rhythms. Chronobiol. Int. 2009, 26, 544-559. [CrossRef] [PubMed]

22. Lennernäs, M.-C.; Hambraeus, L.; Åkerstedt, T. Nutrition and shiftwork: The use of meal classification as a new tool for qualitative/quantitative evaluation of dietary intake in shiftworkers. Ergonomics 1993, 36, 247-254. [CrossRef] [PubMed]

23. Lowden, A.; Moreno, C.; Holmbäck, U.; Lennernäs, M.; Tucker, P. Eating and shift work—Effects on habits, metabolism, and performance. Scand. J. Work Environ. Health 2010, 36, 150-162. [CrossRef]

24. Nicholls, R.; Perry, L.; Duffield, C.; Gallagher, R.; Pierce, H. Barriers and facilitators to healthy eating for nurses in the workplace: An integrative review. J. Adv. Nurs. 2016, 73, 1051-1065. [CrossRef]

25. Haugaard, P.; Stancu, C.M.; Brockhoff, P.B.; Thorsdottir, I.; Lähteenmäki, L. Determinants of meal satisfaction in a workplace environment. Appetite 2016, 105, 195-203. [CrossRef]

26. Nyberg, M.; Lennernäs Wiklund, M. Impossible meals? The food and meal situation of flight attendants in Scandinavia-A qualitative interview study. Appetite 2017, 113, 162-171. [CrossRef] [PubMed]

27. Scander, H.; Yngve, A.; Lennernäs Wiklund, M. Assessing commensality in research. Int. J. Environ. Res. Public Health 2021, 18, 2632. [CrossRef]

28. Munn, Z.; Peters, M.D.; Stern, C.; Tufanaru, C.; McArthur, A.; Aromataris, E. Systematic review or scoping review? Guidance for authors when choosing between a systematic or scoping review approach. BMC Med Res. Methodol. 2018, 18, 143. [CrossRef] [PubMed]

29. Arksey, H.; O'Malley, L. Scoping studies: Towards a methodological framework. Int. J. Soc. Res. Methodol. 2005, 8, 19-32. [CrossRef]

30. Mestdag, I.; Vandeweyer, J. Where has family time gone? In search of joint family activities and the role of the family meal in 1966 and 1999. J. Fam. Hist. 2005, 30, 304-323. [CrossRef]

31. Mestdag, I.; Glorieux, I. Change and stability in commensality patterns: A comparative analysis of Belgian time-use data from 1966, 1999 and 2004. Sociol. Rev. 2009, 57, 703-726. [CrossRef]

32. Mestdag, I. Disappearance of the traditional meal: Temporal, social and spatial destructuration. Appetite 2005, 45, 62-74. [CrossRef] [PubMed]

33. Kim, S. Solitary eating, an inferior alternative? An examination of time-use data in South Korea. Int. Sociol. 2020, 35, 415-432. [CrossRef]

34. Takeda, W.; Melby, M.K.; Ishikawa, Y. Who eats with family and how often? Household members and work styles influence frequency of family meals in urban Japan. Appetite 2018, 125, 160-171. [CrossRef] [PubMed]

35. Darmon, I.; Warde, A. Habits and orders of everyday life: Commensal adjustment in Anglo-French couples. Br. J. Sociol. 2019, 70, 1025-1042. [CrossRef] [PubMed]

36. Giacoman, C.; Lhuissier, A.; Ferrant, C.; Bórquez, I.; Devilat, D. Meal synchronization and commensality in Santiago and Paris. Appetite 2021, 159, 105065. [CrossRef]

37. Lhuissier, A.; Giacoman, C.; Ferrant, C.; Devilat, D.; Leal, D.; Ayala, P.; Torres, G.; Chauvin, P. Meal times and synchronization: A cross-metropolitan comparison between Santiago (Chile) and Paris (France). Soc. Sci. J. 2020, 57, 470-484. [CrossRef]

38. Yates, L.; Warde, A. Eating together and eating alone: Meal arrangements in British households. Br. J. Sociol. 2017, 68, 97-118. [CrossRef] [PubMed]

39. Holm, L.; Lauridsen, D.; Lund, T.B.; Gronow, J.; Niva, M.; Makela, J. Changes in the social context and conduct of eating in four Nordic countries between 1997 and 2012. Appetite 2016, 103, 358-368. [CrossRef] [PubMed]

40. Johnson, R.K. Dietary intake-How do we measure what people are really eating? Obesity 2002, 10, 63S. [CrossRef] [PubMed]

41. Medical Research Center. Estimated Food Diaries. 2020. Available online: https://www.measurement-toolkit.mrc.ac.uk/diet/ subjective-methods / estimated-food-diaries (accessed on 30 November 2020).

42. Office for National Statistics Social Survey Division. Annual Population Survey, July 2019-June 2020. In Data Collection, 3rd ed.; SN: 8685; UK Data Service: Manchester, UK, 2021. [CrossRef]

43. National Research Council. The Subjective Well-Being Module of the American Time Use Survey: Assessment for its Continuation; 0309266645; National Research Council: Washington, DC, USA, 2012. 
44. Statistics Sweden. Time-Use Survey; SCB: Stockholm, Sweden, 2002.

45. Tellström, R. The Construction of Food and Meal Culture for Political and Commercial Ends: EU-Summits, Rural Businesses and World Exhibitions. Ph.D. Thesis, Örebro University, Örebro, Sweden, 2006.

46. Vesnaver, E.; Keller, H.H.; Sutherland, O.; Maitland, S.B.; Locher, J.L. Alone at the table: Food behavior and the loss of commensality in widowhood. J. Gerontol. Ser. B Psychol. Sci. Soc. Sci. 2016, 71, 1059-1069. [CrossRef] [PubMed]

47. Centers for Disease Control and Prevention (CDC); National Center for Health Statistics (NCHS). Analytic and Reporting Guidelines: The National Health and Nutrition Examination Survey (NHANES). Available online: http://www.cdc.gov/nchs/ data/nhanes/nhanes_03_04/nhanes_analytic_guidelines_dec_2005.pdf (accessed on 16 May 2018).

48. Yngve, A.; Neuman, N.; Haapala, I.; Scander, H. The Project Collection Food, Nutrition and Health, with a Focus on Eating Together. Int. J. Environ. Res. Public Health 2021, 18, 1572. [CrossRef] [PubMed] 